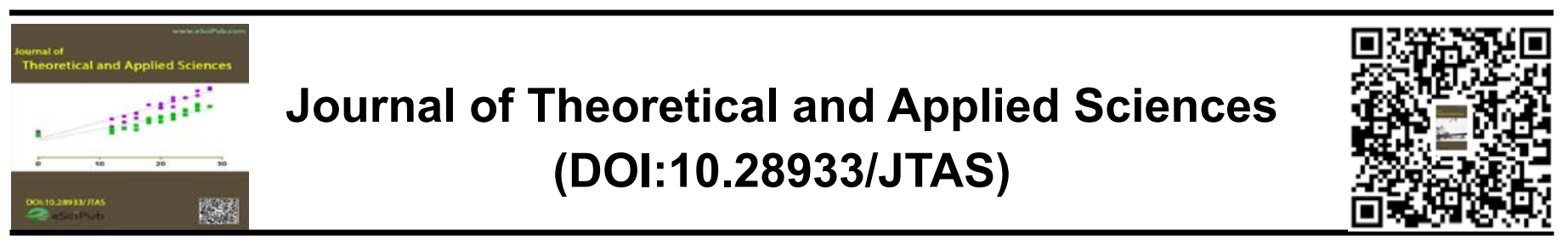

\title{
Shantala as nursing practice in children's health
}

\author{
Santos R.G1, Oliveira M.A.C2; Cordeiro R.F3, Macedo T.A4, Sousa V.J5
}

${ }^{1}$ Graduating in Nursing at the University Center Dr. Tabosa de Almeida - ASCES-UNITA; 2, 3, 4 Graduating in Nursing at the University Center Dr. Tabosa de Almeida - ASCES-UNITA; 5Docente of the Nursing Course of ASCES-UNITA, Master in Child and Adolescent Health.

\begin{abstract}
Introduction: The Indian Shantala Technique has been recognized and employed by various groups around the world, first inspired by the doctor obstetrician Frédérick Leboyer in 1976, understands that the first essays of a child's life are structural and formative, several authors agree that the massage method brings improvements to both mother and child, and the mother performs. This exchange provides experiences that perpetuate the importance of this unique and fundamental bond to a baby's healthy development. (BERNSMULLER, 2012). Objectives: To demonstrate the importance of teaching and stimulating Shantala in childcare. Methodology: This study is a review of bibliographic literature of the descriptive type, enabling a systematized research on the issues addressed in the scientific field, having this as the conducting question of research: How important is the nurse to stimulate and teach Shantala in childcare? Being researched in the main data bases: Lilacs, Scielo, Bireme, BVS. As inclusion criteria were considered: articles, theses and monographs available in full format, between 2010 and 2016. Results and Discussion: Through Shantala beyond the mother / child bond be strengthened, as it is an act of love, being more than a massage, it is also possible to obtain results like calmer sleep, decrease of colic, better functioning of the intestine, among others. (MOURA et al, 2015). The body massage helps to make information about the baby perceptible, so that the baby receives answers that allow adjustments in their needs. (BÁRCIA and VERÍSSIMO, 2010). Conclusion: Through this natural and conscious physiological integration, there is an exchange that results in strengthening and increasing the mother / baby bond, as well as physical and psychic health. (BERNSMULLER, 2012).
\end{abstract}

\section{${ }^{*}$ Correspondence to Author:} Santos R.G

Graduating in Nursing at the University Center Dr. Tabosa de Almeida - ASCES-UNITA

How to cite this article:

Santos R.G, Oliveira M.A.C; Cordeiro R.F, Macedo T.A, Sousa V.J. Shantala as nursing practice in children's health.Journal of Theoretical and Applied Sciences, 2018, 1:4

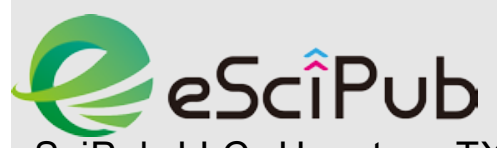

eSciPub LLC, Houston, TX USA. Website: http://escipub.com/

Keywords: Massage; Childhood; Child Health 